\title{
Antibiotic Application and Resistance in Swine Production in China: Current Situation and Future Perspectives
}

\author{
Hong Yang ${ }^{1,2+}$, Lisa Paruch ${ }^{1 \dagger}$, Xunji Chen ${ }^{3}$, André van Eerde ${ }^{1}$, Hanne Skomedal ${ }^{1}$, \\ Yanliang Wang ${ }^{1}$, Di Liu ${ }^{4 *}$ and Jihong Liu Clarke ${ }^{1 *}$ \\ ${ }^{1}$ Norwegian Institute of Bioeconomy Research, Ås, Norway, ${ }^{2}$ Department of Geography and Environmental Science, \\ University of Reading, Reading, United Kingdom, ${ }^{3}$ Xinjiang Academy of Agricultural Sciences, Urumqi, China, ${ }^{4}$ Heilongjiang \\ Academy of Agricultural Sciences, Harbin, China
}

OPEN ACCESS

Edited by:

Rajesh Jha

University of Hawaii At Manoa,

United States

Reviewed by:

Xiao Xu

Wuhan Polytechnic University, China Sungkwonk Park,

Sejong University, South Korea

*Correspondence:

Di LiU

liudi1963@163.com

Jihong Liu Clarke

Jihong.liu-clarke@nibio.no

these authors have contributed equally to this work

Specialty section:

This article was submitted to Animal Nutrition and Metabolism,

a section of the journal

Frontiers in Veterinary Science

Received: 14 December 2018 Accepted: 10 April 2019 Published: 17 May 2019

Citation:

Yang $H$, Paruch $L$, Chen $X$, van Eerde A, Skomedal H, Wang Y, Liu D and Liu Clarke J (2019) Antibiotic Application and Resistance in Swine Production in China: Current Situation and Future Perspectives.

Front. Vet. Sci. 6:136 doi: 10.3389/fvets.2019.00136
To meet increasing demand for animal protein, swine have been raised in large Chinese farms widely, using antibiotics as growth promoter. However, improper use of antibiotics has caused serious environmental and health risks, in particular Antimicrobial resistance (AMR). This paper reviews the consumption of antibiotics in swine production as well as AMR and the development of novel antibiotics or alternatives in China. The estimated application of antibiotics in animal production in China accounted for about 84240 tons in 2013. Overuse and abuse of antibiotics pose a great health risk to people through foodborne antibiotic residues and selection for antibiotic resistance. China unveiled a national plan to tackle antibiotic resistance in August 2016, but more support is needed for the development of new antibiotics or alternatives like plant extracts. Antibiotic resistance has been a major global challenge, so international collaboration between China and Europe is needed.

Keywords: antibiotics, antimicrobial resistance, bacteria, China, human and animal health, swine production

\section{INTRODUCTION}

Over the last decades, China's economy has grown very quickly. The gross domestic product (GDP) increased from 1.21 trillion US\$ in 2000 to 10.35 trillion US\$ in 2014 (Figure 1, World Bank, 2016). During the same period, Chinese production of meat, eggs, and milk has rapidly increased, and this will continue-especially for pork (1-3). Pork is one of the most important sources of animal protein in the country, and its production has jumped from around 40 million tons in 2000 to approximately 56 million tons in 2014 (Figure 1, USDA, 2016). The effects of the global financial crisis in 2007 and swine flu in 2011 caused an AMRupt production decline in these 2 years. However, production of swine quickly rebounded in the subsequent years. Concurrently, China's pork consumption increased from 2000 to 2014, with some drops in 2007 and 2011. Since 2012 , pork consumption has been slightly higher than production, indicating that the pork demand of Chinese consumers has exceeded the domestic production.

Along with a rapid increase in pork production, both the number and the size of intensive swine farms have grown. The number of big farms with thousands of swine has increased markedly. The percentage of big swine farms, with herd sizes of more than 3,000, increased from 5\% in 2003 to $14 \%$ in 2010. In the same period, the proportion of small farms, with herd sizes of less than 50 , nearly halved, from 71\% to 36\% (China Animal Industry Yearbook 2004-2011).

Several recent studies detail antibiotic use in animal production (3-6) and the risk this poses in the form of antibiotic resistance (7-9). The current study focuses on the important emerging public health challenges as a result of overuse or abuse of antibiotics in swine production in China. It also outlines the future challenges for the new antibiotics and alternatives. 


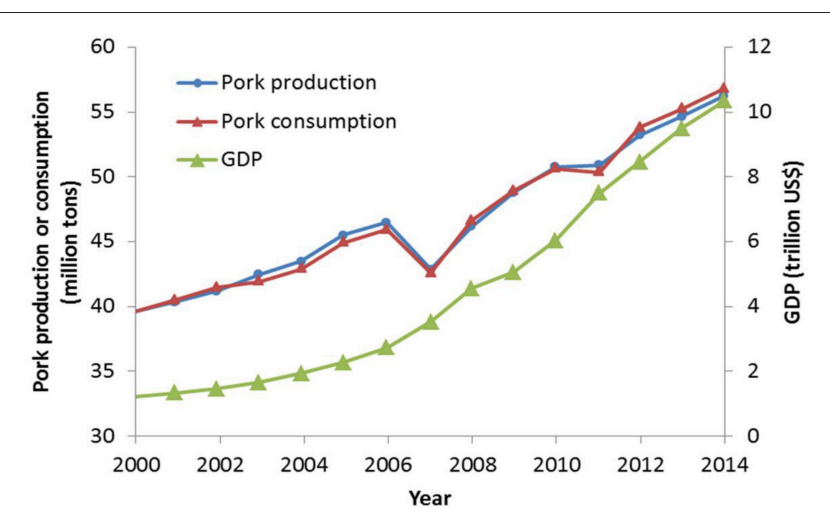

FIGURE 1 | Gross domestic production (GDP), pork production and consumption in China from 2000 to 2014 (data source: World Bank http:// data.worldbank.org/country/china and USDA Foreign Agricultural Service http://www.fas.usda.gov/).

\section{ANTIBIOTIC USAGE IN SWINE PRODUCTION IN CHINA}

With the shift from small to large swine feeding operations and the increase in overall pork production, there is growing concern about the adverse consequences such as swine health and welfare, disease spreading of large-scale animal production (1). Because the high density of animals in big swine farms exacerbates the risk of quick spread of infectious diseases, farmers in China have responded by using higher amounts of antibiotics. This, in turn, has led to growing concerns regarding overuse and abuse of antibiotics for intensive swine production, especially the health risks $(3,10,11)$.

Penicillin was discovered in the 1940s. Since then, antibiotics have changed the treatment of bacterial infections for both humans and animals. Antibiotics were first added to feed for broiler poultry to prevent microbial diseases in the 1940s (12). They were then rapidly used for the same purpose in feed for other food animals, first in the USA and later in other developed countries and developing countries such as China (2). Antibiotics can aid in different ways. When antibiotics are used at low (sub-therapeutic) levels in feed, they can improve growth rate by reducing mortality and disease. Thus, conversion of feed to weight gain becomes more efficient. Antibiotics can further prevent disease at intermediate levels, whereas high (therapeutic) levels of antibiotics are used to treat diseases (1315). Antibiotics are widely used in animal husbandry as low-cost growth promoters in more than half of the world's countries (7).

As the world's largest pork producer and consumer, China uses a massive amount of antibiotics to support its production (3). Some studies have been conducted to identify the antibiotics used in China's pig farms (16-23). These studies report the extensive use of the major antibiotic classes of sulphonamides, tetracyclines, fluoroquinolones, macrolides, and $\beta$-lactams.

Antibiotics have been widely adopted for use in food animals, but reliable data about the quantity and patterns of use (e.g., dose and frequency) for food animals alone are not easily available in China or other developing countries. It is very challenging to make an accurate calculation of antibiotic use in food animals. Studies have adopted different classifications for therapeutic use, nontherapeutic use, or a combination of the two. Most available data lack clear definition of therapeutic vs. nontherapeutic uses, and this ambiguity clearly erodes reliability (24). Based on models developed from American data (25), Krishnasamy et al. (24) estimated that 38.5 million $\mathrm{kg}$ of antimicrobials were consumed in China's pork and poultry production in 2012. Among all antibiotics, tetracyclines are the most widely consumed in swine production. Zhang et al. (23) performed a market survey on the usage of the 36 main antibiotics in China including sulfonamides, tetracyclines, fluoroquinolones, macrolides, $\beta$ lactams (penicillins and cephalosporins), chloramphenicols, lincomycin, and others. They found that the total amount of antibiotics used for China's swine farming was 48.4 million $\mathrm{kg}$ in 2013, which is higher than the result of Krishnasamy et al. (24). Of all antibiotics consumed in China's swine farming, fluoroquinolones and $\beta$-lactams contributed more than half.

Moreover, there is a clear geographic heterogeneity for antibiotic consumption in China. Antibiotic consumption hotspots appear in Southwest China (Sichuan), Central China (Hunan), North China (Henan and Hebei) and the southeast coast (Fujian, Guangdong and Guangxi) in China. In particular, Sichuan province has the highest swine density and therefore carries the most serious risks to environment and health (23). Other areas have also seen significant developments in recent years. For example, Xinjiang Uyghur Autonomous Region, the provincial level region with the largest area in Northwest China, is located in the center of the Eurasian continent. It is in the core area of "The Silk Road Economic Belt" and plays an important role in this program. Pork production in Xinjiang increased from 0.025 million tons in 1978 to 0.231 million tons in 2010 (Statistical Yearbook of Xinjiang in 2011). Despite a lack of data on antibiotic consumption in swine farms in Xinjiang, the concentration and detection rate of antibiotic residue in swine manure samples were higher than those of chicken manure and cow dung. The concentration of tetracycline in swine manure was highest, followed by sulfonamides and quinolones (26, 27). Additionally, international trade with Central Asian and European countries is increasing along the Silk Road, which may worsen the spread of antibiotics. In Lake Aibi, 12 species of 14 kinds of antibiotics were detected and detection rates of four kinds of antibiotics were $100 \%$ in water samples, with highest average concentration of $54.37 \mathrm{ng} \mathrm{L}^{-1}(28,29)$.

China is tackling the overuse of antibiotics and the AMR problem using different approaches, including educating farmers about AMR caused by excessive use of antibiotics in animal farming, swiftly banning the use of colistin as a feed additive in animal production (30), reducing the list of approved antibiotics for animal application, promoting the use of alternative feed additives such as organic acids (e.g., Selko ${ }^{\circledR}-\mathrm{pH}$, http://selko. com), improving the management of animal husbandry and animal welfare, and law enforcement accompanied by an effective surveillance system [(3), http://www.moa.gov.cn/]. 


\section{ANTIBIOTIC RESISTANCE AND THE RISK TO HUMAN HEALTH}

The overuse and abuse of antibiotics cause environmental pollution, for example the contamination of manure, soil and water $(10,31)$. Worse, improper use of antibiotics brings risk to human health through food-borne antibiotic residues and selection for AMR, and a greater ability of certain bacteria to resist the effect of antibiotic treatments (7). The causes of AMR are complex, but there is growing scientific evidence suggesting that low-dose, prolonged courses of antibiotic use for animal husbandry accelerated the emergence and spread of resistant bacteria (32-34). In food animal husbandry, AMR can spread not only by direct contact, but also indirectly (Figure 2). Direct effects are those that can be causally linked to contact with antibiotic-resistant bacteria from swine. Indirect effects are those that result from contact with resistant organisms that have been spread through food, water, and animal waste application to soil (37).

Many antibiotic classes are used in both swine husbandry and human health care. Therefore, the emergence and spread of resistance to these antibiotics will likely limit the therapeutic options for human diseases. Even worse, this kind of AMR can prolong illness and cause serious disability and ultimately death $(32,33)$.

In the last decades, AMR has become a global challenge for human health and welfare. In particular, it is a serious problem in China where antibiotics have been overused or misused in livestock husbandry and human health care (38-41). For example, the OqxAB efflux pump, encoded by the genes oq $x A$ and $\operatorname{oq} x B$, has been found to be one of the mechanisms of plasmid-mediated quinolone resistance (PMQR) (42-44). Zhao et al. (45) investigated the prevalence and dissemination of oq $x A B$ in Escherichia coli (E. coli) isolates from swine, their environment and farmworkers in China. The oqxA gene was present in around $39.0 \%$ of $E$. coli isolates. About $46.3 \%$ of $E$. coli isolates from swine farms were positive for oqxA. Approximately $43.9 \%$ of $E$. coli isolates from the swine farm environment were also positive. In addition to animal E. coli isolates, oq $x A B$ was found in $30.3 \%$ of human commensal E. coli isolates. Because these farmworkers were without previous antimicrobial treatment or hospital admission, this indicated the transmission of $o q x A B$ to humans. Compared with results from Sweden (1.8\%) and South Korea $(0.4 \%)(46,47)$, the prevalence of oq $x A B$ in E. coli isolates was much higher (39.0\%) in China (45).

A further example has been reported by Zhang et al. (48), who researched the occurrence of the aac (3)-IV gene, which confers resistance to apramycin, an antibiotic used in agriculture but not for humans, in Northeast China. Unfortunately, they found workers who carried apramycin resistance genes in all swine farms where apramycin was used as an antibiotic growth promoter. The same was present in swine isolates. Similarly, Ho et al. (49) investigated gentamicin resistance in Hong Kong. They found that $84.1 \%$ of human samples and $71.4 \%$ of swine samples contained the aaaC2 gene for gentamicin resistance. Polymyxin resistance was identified as being due to the plasmid-mediated $m c r-1$ gene (50). Liu et al. (51) investigated the $m c r-1$ gene in swine, pork and inpatients in five provinces in China during the period 2011-2014. They found $m c r-1$ in E. coli isolates collected from $17.7 \%$ of pork samples, $20.23 \%$ of swine samples, and $1.40 \%$ of inpatient samples with infection. Similar studies have also been conducted in Xinjiang. For example, Xia et al. (52) collected 543 fecal samples from a large-scale swine farm and isolated 454 E. coli isolates. They found that $64.5 \%$ of the E. coli isolates showed resistance to 3-9 antimicrobials, especially to ampicillin and amoxicillin.

\section{THE DEVELOPMENT OF NEW ANTIBIOTICS}

Concern about antibiotic resistance has escalated in the last years. In 1986, Sweden became the first country in the world to ban the use of some antibiotics in animal feeds (53). In 2006, European Union (EU) member nations started to ban all antibiotic growth promoters according to EC Regulation No. 1831/2003 (14). As the largest developing country with a growing demand for meat protein, China has not yet completely prohibited the use of antibiotics as growth promoters. Considering the big risk for antibiotic pollution in the environment (soil and water) and potential resistance, more research is urgently needed for the development of new antibiotics or, ideally, alternatives.

\section{New Antibiotics}

During the past two decades, efforts to develop new antibiotics have met with some success (54). However, due to their much higher costs compared to the older antibiotics, many have been gradually pulled from the market. Therefore, new antibiotics are still needed to tackle the worsening risk of antibiotic resistance.

Several approaches have been applied to identify new antibiotics or augment currently licensed antibiotics: (1) natural or synthetic compounds as inhibitors of multidrug efflux pumps, (2) small-molecule inhibitors of bacterial transcription factors, and 3) antisense inhibition of multidrug transporter genes using licensed drugs (55-59). As alternatives to antibiotics, use of bacteriophage and plant extracts has also been investigated, which will be discussed in the next section.

By deleting or inactivating specific genes, researchers found some putative new targets, for example reducing the virulence of pathogens $(60,61)$. Quorum sensing (QS) or other bacterial signaling systems have also been identified as new targets for antibiotic molecules $(62,63)$. In-silico and in vitro highthroughput screening of small-molecule and compound libraries have also been increasingly used. Some agents have been in Phase 1 of clinical trials (64). In 2015, Ling et al. (65) discovered a "resistance-free" teixobactin in a screen of uncultured soil bacteria sample. Experiments confirmed no mutants of Staphylococcus aureus or Mycobacterium tuberculosis resistant to this teixobactin. Hopefully, this study will start an innovative approach to expanding the pool of natural antibiotics (66). Recently, a new class of antibiotics-arylomycins-was reported (67). The arylomycin G0775 showed activity against multi-drug resistant Gram-negative clinical bacterial pathogens by inhibiting the essential bacterial type I signal peptidase (which 


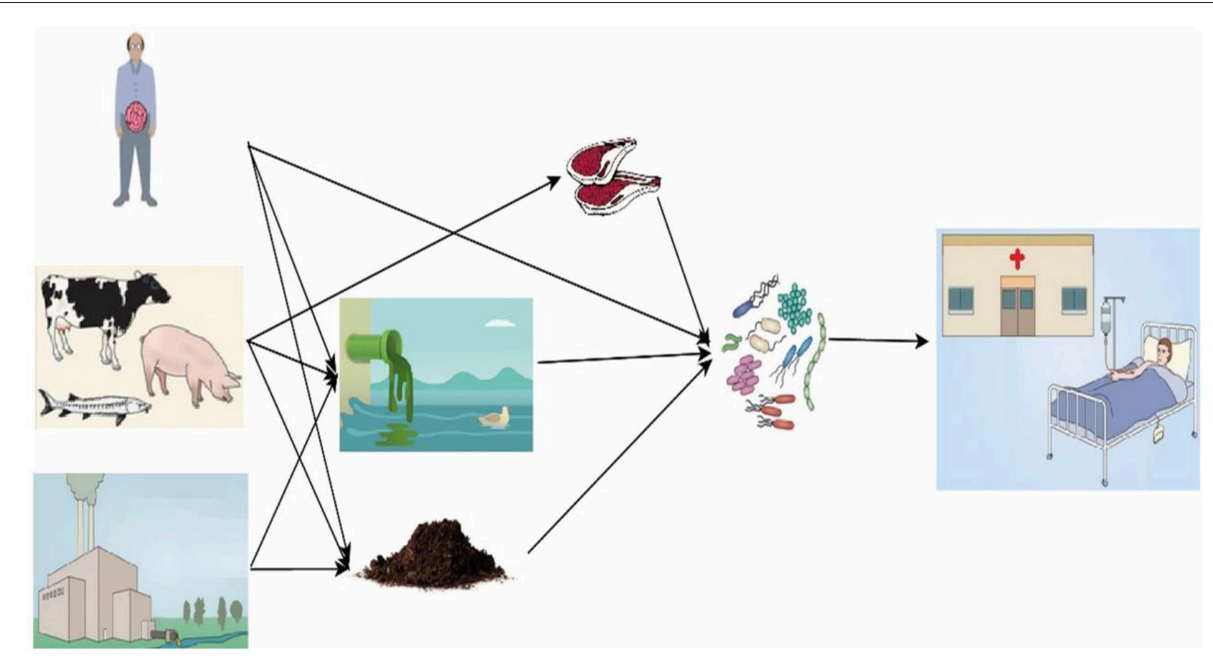

FIGURE 2 | Expected fate, transport, and exposure pathways for antibiotics and the spread of antibiotic resistome. Antibiotics from human and veterinary drugs, growth promoter for animal husbandry and aquaculture, and improper release during pharmaceutical production are released into water and soil. Manure containing antibiotic resistome may be carelessly used for crop production. Antibiotic resistome can remain in meat and the bacteria can be further spread to humans. People take up antibiotics and resistome develops in their guts [modified from Song and guo (35) and Berendonk et al. (36)].

is a novel antibiotic target) through an unknown mechanism as described by Smith et al. (67). Further investigation will hopefully reveal the molecular mechanism underlying this novel class of antibiotics originating from natural products. Efforts will be made to identify and characterize more novel natural products to tackle AMR and problems caused by over-application of antibiotics in swine production.

\section{Plant Extracts-a Promising Alternative}

In addition to searching for new antibiotics, alternatives/replacements have received growing attention in the last decades $(14,68)$. Researchers have explored various kinds of alternatives to animal antibiotics: feeding enzymes, immunity modulating agents, bacteriophages and their lysines, antimicrobial peptides, probiotics, prebiotics, synbiotics, inhibitors targeting pathogenicity, plant extracts and others (14, 69-75). In China, herbs and their extracts have been widely used in traditional medicine for centuries before the introduction of western medicine. Youyou Tu, from the China Academy of Traditional Chinese Medicine in Beijing, was awarded the 2015 Nobel Prize in Physiology or Medicine for her discovery of artemisinin (qinghaosu) extracted from Artemisia annua L. (76). Her work was inspired by the Chinese traditional medical book Prescriptions for Emergencies by Ge Hong (284-346 CE) (77). Compared to other antibiotic alternatives, therefore, plant extracts have received more attention and support in China.

Natural plant products and their derivatives have been explored for their antimicrobial, anti-inflammatory, antioxidative, and anti-parasite properties (78-84) (Table 1). A good example is garlic extract, which is widely considered as one of the most effective antibiotic agents (86). In addition, Areca catechu is a rich source of compounds with anti- quorum sensing (QS) properties (87). Some studies also found that $P$. aeruginosa genes controlled by QS could be inhibited by the isothiocyanate iberin from horseradish and ajoene from garlic $(88,89)$. When they are combined with tobramycin, ajoene and horseradish juice extracts function as a synergistic antibacterial (90). Extracts of the genus Paeonia, one of the most important sources of drugs in Chinese traditional medicine, can inhibit $C$. albicans growth (91). Extracts from Fructus psoraleae, Folium eucalypti globuli and Achillea millefolium, anti-dermatophitic compounds, have been used to treat different ailments such as dermatomycosis in Chinese traditional medicines $(92,93)$.

Diarrhea is a common cause of intestinal diseases in children and animals including swine (94). Some studies have been conducted to find plant extracts for inhibiting the proliferation of E. coli. Khan et al. (95) found that pathogenic strains of E. coli are sensitive to the extracts of three plants (Acacia nilotica, Syzygium aromaticum and Cinnamum zeylanicum). Herb extracts from Pulsatilla chinensis, Sophora flavescens, Phellodendron amurense, Radix Astragali and Codonopsis pilosula (Franch) Nannf have been used to treat diarrhea of piglets in Chongqing, Southwest China (96). Because of the influence of harvesting method and other unknown factors (97), plant extracts have been limited by their variability (98). The current high cost also limits the wide use of herb extracts, but the further development of herb extracts may reduce the cost and expand their application in developing countries.

Xinjiang is one of the Chinese regions with high biodiversity. The flora include common bitter beans, Cynomorium, Ephedra, Ferula, liquorice, snow lotus, sea buckthorn, and others. Among these, bitter beans have antibacterial ingredients (99). Horse grass contains alkaloids that, when drunk, can inhibit the function of malignant tumors. Xinjiang Lithospermum and liquorice contain glycyrrhizinate, flavonoids and other medicinal ingredients. These plant ingredients have antibacterial effects on E. coli, paratyphoid Salmonella, Staphylococcus aureus, Bacillus subtilis and other common pathogens (100). 
TABLE 1 | Antibiotic alternatives: plant extracts.

\begin{tabular}{|c|c|c|}
\hline Plant & Effect observed & References \\
\hline $\begin{array}{l}\text { Aged garlic extract, } \\
\text { allicin }\end{array}$ & $\begin{array}{l}\text { Improved growth performance, } \\
\text { nutrient digestibility, intestinal } \\
\text { microbial balance, immune response } \\
\text { and meat quality in finishing pigs }\end{array}$ & (82) \\
\hline Camellia sinensis & $\begin{array}{l}\text { Improved gut health of post-weaning } \\
\text { piglets and protection from E.coli } \\
\text { challenge }\end{array}$ & (81) \\
\hline $\begin{array}{l}\text { Cinnamon essential } \\
\text { oils, Cinnamaldehyde }\end{array}$ & $\begin{array}{l}\text { Antimicrobial activity and improved } \\
\text { immune response against e.g., } \\
\text { Salmonella typhimurium in swine } \\
\text { intestine }\end{array}$ & (83) \\
\hline $\begin{array}{l}\text { Carvacrol, } \\
\text { cinnamaldehye, } \\
\text { eugenol, etc. }\end{array}$ & $\begin{array}{l}\text { Anti-inflammatory effects on porcine } \\
\text { alveolar macrophages }\end{array}$ & (78) \\
\hline $\begin{array}{l}\text { Capsicum oleoresin, } \\
\text { turmeric oleoresin, } \\
\text { garlicon }\end{array}$ & $\begin{array}{l}\text { Improved gut health and reduced } \\
\text { frequency of diarrhea in weanling } \\
\text { pigs }\end{array}$ & $(79,80)$ \\
\hline Agrimonia procera & $\begin{array}{l}\text { Growth performance, increased } \\
\text { immune response and antioxidative } \\
\text { effects in piglets }\end{array}$ & (84) \\
\hline $\begin{array}{l}\text { Chinese traditional } \\
\text { herbal medicine } \\
\text { (CTHM) }\end{array}$ & $\begin{array}{l}\text { Beneficial effects on swine growth } \\
\text { with improved final live weight, } \\
\text { general digestibility and nitrogen } \\
\text { retention }\end{array}$ & (85) \\
\hline
\end{tabular}

\section{Future Perspective and Conclusions}

Global organizations and developed countries have paid increasing attention to tackling the great risks of overuse and abuse of antibiotics and antibiotic resistance (101). For example, the World Health Assembly (WHA) commissioned the WHO to deliver a global action plan on antibiotic resistance in May 2014. The British government sponsored the $£ 10$ million Longitude Prize for the best solution for the resistance problem in June 2014. The President's Council of Advisors on Science and Technology in the USA released a report on antibiotic resistance in September 2014.

Slower than many European countries and the USA, China unveiled a national plan to tackle antibiotic resistance in August 2016 (102). The plan highlights the importance of reducing use of antibiotics in China's livestock husbandry. However, the

\section{REFERENCES}

1. Yang H. Livestock development in China: animal production, consumption and genetic resources. J Anim Breed Genet. (2013) 130:249-51. doi: 10.1111/jbg. 12045

2. He Y, Yang XG, Xia J, Zhao LY, Yang YX. Consumption of meat and dairy products in China: a review. Proc Nutri Society. (2016) 75:385-91. doi: 10.1017/S0029665116000641

3. Li, J. (2017). Current status and prospects for in-feed antibiotics in the different stages of pork production- a review. Asian Austr J Animal Sci. 30:1667-73. doi: 10.5713/ajas.17.0418t

4. Tang KL, Caffrey NP, Nóbrega DB, Cork SC, Ronksley PE, Barkema HW, et al. Restricting the use of antibiotics in food-producing animals and its associations with antibiotic resistance in food-producing animals and human implementation details of the plan are still unclear. Punishment for violations is still lacking. As for many action plans and laws in China, strict implementation is extremely important for reducing the use of antibiotics $(103,104)$. The plan also emphasizes the development of new antibiotics. As stated above, the high price of new antibiotics and alternatives limits their development (54). In the action plan, the funding source for discovery of new antibiotics or alternatives, for example from government or industry, is still unclear. Antibiotics have been widely overused and abused in Chinese swine farms to prevent diseases. However, it is more important to improve the sanitation and hygiene conditions of swine farms. Rather than using antibiotics, some measures should be applied to improve the health and wellbeing of swine, in particular reducing animal overcrowding, and controlling facility temperature and ventilation. In addition to the swine farmers, joint efforts from government, academia and veterinary professionals are indispensable.

Antibiotic resistance has become a world-wide challenge and therefore international collaboration is increasingly crucial. International collaboration between the world's largest antibiotics consumers, China and Europe, is indispensable to tackle the AMR problem. The One Health approach is of importance to achieve a sustainable and effective management of AMR by joint efforts of the international community with involvement of all stakeholders.

\section{AUTHOR CONTRIBUTIONS}

JC and DL designed the review, contributed to writing and editing. HY, LP, XC, AvE, HS, and YW contributed to writing, while JC is responsible for submission.

\section{FUNDING}

This work is supported by Sinograin and Sinograin II projects with $\mathrm{JC}$ as the project manager.

\section{ACKNOWLEDGMENTS}

This work was supported by the Sinograin project and a pilot project Biotransformation supported by NIBIO core funding. The authors thank Prof. Nicholas Clarke for linguistic correction.

beings: a systematic review and meta-analysis. Lancet Planet Health. (2017) 1:316-27. doi: 10.1016/S2542-5196(17)30141-9

5. Menkem ZE, Ngangom BL, Tamunjoh SSA, Boyom FF. Antibiotic residues in food animals: Public health concern. Acta Ecologica Sinica. (2018). doi: 10.1016/j.chnacs.2018.10.004.

6. Bacanli M, Başaran N. Importance of antibiotic residues in animal food. Food Chem Toxicol. (2019) 125:462-6. doi: 10.1016/j.fct.2019.01.033

7. WHO. (2014). Antimicrobial Resistance: Global Report on Surveillance. Geneva.

8. Cameron A, McAllister TA. Antimicrobial usage and resistance in beef produciton. J Animal Sci. 7:68. doi: 10.1186/s40104-016-0127-3

9. Xiong W, Sun YX, Zeng Z. Antimicrobial use and antimicrobial resistance in food animals. Env Sci Pollu Res. (2018) 25:18377-284. doi: $10.1007 / \mathrm{s} 11356-018-1852-2$ 
10. Sarmah AK, Meyer MT, Boxall ABA. A global perspective on the use, sales, exposure pathways, occurrence, fate and effects of veterinary antibiotics (VAs) in the environment. Chemosphere. (2006) 65:725-59. doi: 10.1016/j.chemosphere.2006.03.026

11. Milanov DS, Ljubojević DB, Cabarkapa IS, Aleksić NŽ. Impact of antibiotics used as growth promoters on bacterial resistance. Food Feed Res. (2016) 43:83-92. doi: 10.5937/FFR1602083M

12. Stokstad ELR, Jukes TH, Pierce J, Page AC, Franklin AL. The multiple nature of the animal protein factor. J Biol Chem. (1949) 180:647-54.

13. Cromwell GL. Why and how antibiotics are used in swine production. Anim Biotechnol. (2002) 13:7-27. doi: 10.1081/ABIO-120005767

14. Cheng GY, Hao HH, Xie SY, Wang X, Dai MH, Huang LL, et al. Antibiotic alternatives: the substitution of antibiotics in animal husbandry? Front Microbiol. (2014) 5:00217. doi: 10.3389/fmicb.2014.00217

15. Van Epps A, Blaney L. Antibiotic residues in animal waste: occurrence and degradation in conventional agricultural waste management practices. Curr Pollut Rep. (2016) 2:1-21. doi: 10.1007/s40726-016-0037-1

16. Wang J, Han JZ. Effects of heavy metals and antibiotics on soil and vegetables. J Ecol Rural Environ. (2008) 24:90-3. doi: 10.3969/j.issn.1673-4831.200 8.04.019

17. Zhang $\mathrm{H}$, Luo $\mathrm{Y}$, Zhou Q. Research advancement of eco-toxicity of tetracycline antibiotics. J Agro-Environ Sci. (2008) 27:407-13. doi: 10.3321/j.issn:1672-2043.2008.02.001

18. Zhang H, Zhang M, Gu G. Residues of tetracyclines in livestock and poultry manures and agricultural soils from North Zhejiang Province. J Ecol Rural Environ. (2008) 24:69-73. doi: 10.3969/j.issn.1673-4831.2008.03.014

19. Zhang M, Wang L, Zheng S. Adsorption and transport characteristics of two exterior-source antibiotics in some agricultural soils. Acta Eco Sin. (2008) 28:761-6. doi: 10.3321/j.issn:1000-0933.2008.02.038

20. Li Y, Mo C, Zhao N, Tai Y, Bao Y, Wang J, et al. Investigation of sulfonamides and tetracyclines antibiotics in soils from various vegetable fields. Environ Sci. (2009) 30:1762-6. doi: 10.3321/j.issn:0250-3301.2009.06.035

21. Tai Y, Mo C, Li Y, Wu X, Zou X, Gao P, et al. Concentration and distribution of quinolone antibiotics in long-term manure-amended soils. China Environ Sci. (2010) 30:816-21.

22. Li YW, Wu XL, Mo CH, Tai YP, Huang XP, Xiang L. Investigation of sulfonamide, tetracycline, and quinolone antibiotics in vegetable farmland soil in the Pearl River Delta area, southern China. J Agric Food Chem. (2011) 59:7268-76. doi: 10.1021/jf1047578

23. Zhang QQ, Ying GG, Pan CG, Liu YS, Zhao JL. Comprehensive evaluation of antibiotics emission and fate in the river basins of China: source analysis, multimedia modeling, and linkage to bacterial resistance. Environ Sci Technol. (2015) 49:6772-82. doi: 10.1021/acs.est.5b00729

24. Krishnasamy V, Otte J, Silbergeld E. Antimicrobial use in Chinese swine and broiler poultry production. Antimicrob Resis Infect Control. (2015) 4:1-9. doi: 10.1186/s13756-015-0050-y

25. Mellon M, Benbrook C, Benbrook K. Hogging It: Estimates of Antimicrobial Abuse in Livestock. (2001). Cambridge, MA: UCS Publications.

26. Ji XL, Liu F, Shen Q. Quantitative detection of sulfonamides and tetracycline antibiotics and their resistance genes in farm wastewater. Chinese $J$ Eco Environ Sci. (2011) 20:927-33. doi: 10.3969/j.issn.1674-5906.2011. 05.025

27. Xia L, Zhao H, Mikeremu S, Cheng T, Gao P. Survey on antibiotic resistance of E.coli isolated from different growth stage pigs in a pig farm of Xinjiang. Chinese J Animal Husb Vet Med. (2013) 40:216-9. doi: 10.3969/j.issn.1671-7236.2013.03.049

28. Cheng J, Yu Z, Michel FC, Morrison M. Development and application of real-time pcr assays for quantification of erm genes conferring resistance to macrolides-lincosamides-streptogramin b in livestock manure and manure management systems. Environ Microbiol. (2007) 73:4407-16. doi: 10.1128/AEM.02799-06

29. Zhou T, Li X, Wang X, Lu J. Pollution analysis of antibiotic resistant genes of manas river basin, Xinjiang. J Shihezi University (Nat Sci Ed). (2014) 32:7559. doi: 10.3969/j.issn.1007-7383.2014.06.018

30. Walsh TR, Wu Y. China bans colistin as a feed additive for animals. Lancet. (2016) 16:1102-3. doi: 10.1016/S1473-3099(16)30329-2

31. Du LF, Liu WK. Occurrence, fate, and ecotoxicity of antibiotics in agro-ecosystems. A review Agron Sustain Dev. (2012) 32:309-27. doi: 10.1007/s13593-011-0062-9
32. Marshall BM, Levy SB. Food animals and antimicrobials: impacts on human health. Clin. Microbiol. Rev. (2011) 24:718-33. doi: 10.1128/CMR.00002-11

33. Mole B. Farming up trouble. Nature. (2013) 499:398-400. doi: 10.1038/499398a

34. Pruden A, Larsson DGJ, Amézquita A, Collignon P, Brandt KK, Graham DW, et al. Management options for reducing the release of antibiotics and antibiotic resistance genes to the environment. Environ Health Perspect. (2013) 121:878-85. doi: 10.1289/ehp.1206446

35. Song W, Guo M. Residual veterinary pharmaceuticals in animal manures and their environmental behaviors in soils. In: He, Z, Zhang, H, editors. Applied Manure and Nutrient Chemistry for Sustainable Agriculture and Environment, London: Springer. p. 23-52. (2014).

36. Berendonk TU, Manaia CM, Merlin C, Fatta-Kassinos D, Cytryn E, Walsh F, et al. Tackling antibiotic resistance: the environmental framework. Nat Rev Microbiol. (2015) 13:310-7. doi: 10.1038/nrmicro3439

37. Landers TF, Cohen B, Wittum TE, Larson EL. A Review of antibiotic use in food animals: perspective, policy, and potential. Public Health Rep. (2012) 127:4-22. doi: 10.1177/003335491212700103

38. Zhang RF, Eggleston K, Rotimi V, Zeckhauser RJ. Antibiotic resistance as a global threat: evidence from China, Kuwait and the United States. Global Health. (2006) 2:1-14. doi: 10.1186/1744-8603-2-6

39. Hvistendahl M. Public health China takes aim at rampant antibiotic resistance. Science. (2012) 336:795. doi: 10.1126/science.336.6083.795

40. Larson C. Pharmaceuticals China's lakes of pig manure spawn antibiotic resistance. Science. (2015) 347:704. doi: 10.1126/science.347.6223.704

41. $\mathrm{Hu} \mathrm{Y}$, Cheng H. Health risk from veterinary antimicrobial use in China's food animal production and its reduction. Environ Pollut. (2016) 219:993-7. doi: 10.1016/j.envpol.2016.04.099

42. Hansen LH, Johannesen E, Burmølle M, Sørensen AH, Sørensen SJ. Plasmid-encoded multidrug efflux pump conferring resistance to olaquindox in Escherichia coli. Antimicrob Agents Chemother. (2004) 48:3332-7. doi: 10.1128/AAC.48.9.3332-3337.2004

43. Li J, Zhang H, Ning J, Sajid A, Cheng G, Yuan Z, et al. The nature and epidemiology of OqxAB, a multidrug efflux pump. Antimicrob Resist Infect Control. (2019) 8:44. doi: 10.1186/s13756-019-0489-3

44. Wang J, Zhi CP, Chen XJ, Guo ZW, Liu WL, Luo J, Huang XY, et al. Characterization of oqxAB in Escherichia coliIsolates from animals, retail meat, and human patients in guangzhou, China. Front Microbiol. (2017) 8:1982. doi: 10.3389/fmicb.2017.01982

45. Zhao JJ, Chen ZL, Chen S, Deng YT, Liu YH, Tian W, et al. Prevalence and Dissemination of oqxAB in Escherichia coli Isolates from Animals, Farmworkers, and the Environment. Antimicrobial Agents Chemother. (2010) 54:4219-24. doi: 10.1128/AAC.00139-10

46. Hansen LH, Sørensen SJ, Jørgensen HS, Jensen LB. The prevalence of the OqxAB amongst olaquindox-resistant multidrug efflux pump Escherichia coli in pigs. Microbial Drug Resist Mech Epidemiol Dis. (2005) 11:378-82. doi: $10.1089 / \mathrm{mdr} .2005 .11 .378$

47. Bin Kim H, Wang MH, Park CH, Kim EC, Jacoby GA, Hooper DC. oqxAB encoding a multidrug efflux pump in human clinical isolates of enterobacteriaceae. Antimicrob Agents Chemother. (2009) 53:3582-4. doi: 10.1128/AAC.01574-08

48. Zhang XY, Ding LJ, Fan MZ. Resistance patterns and detection of aac(3)IV gene in apramycin-resistant Escherichia coli isolated from farm animals and farm workers in northeastern China. Res Vet Sci. (2009) 87:449-54. doi: 10.1016/j.rvsc.2009.05.006

49. Ho PL, Wong RC, Lo SW, Chow KH, Wong SS, Que TL. Genetic identity of aminoglycoside-resistance genes in Escherichia coli isolates from human and animal sources. J Med Microbiol. (2010) 59:702-7. doi: 10.1099/jmm.0.015032-0

50. Webb HE, Granier SA, Marault M, Millemann Y, den Bakker HC, Nightingale KK, et al. Dissemination of the mcr-1 colistin resistance gene. Lancet Infect Dis. (2016) 16:144-5. doi: 10.1016/S1473-3099(15)00538-1

51. Liu YY, Wang Y, Walsh TR, Yi LX, Zhang R, Spencer J, et al. Emergence of plasmid-mediated colistin resistance mechanism MCR-1 in animals and human beings in China: a microbiological and molecular biological study. Lancet Infect Dis. (2016) 16:161-8. doi: 10.1016/S1473-3099(15)00424-7

52. Xia LN, Zhao HQ, Su Y, Guo QY, Chen TT, Gao P. Resistance survey of Escherichia coli isolates to antibiotics from a hoggery in Xinjiang. Xinjiang Agricult Sci. (2012) 49:2299-303. doi: 10.6048/j.issn.1001-4330.2012.12.024 
53. Castanon J. History of the use of antibiotic as growth promoters in European poultry feeds. Poultry Sci. (2007) 86:2466-71. doi: 10.3382/ps.2007-00249

54. Laxminarayan R. Antibiotic effectiveness: Balancing conservation against innovation. Science. (2014) 345:1299-301. doi: 10.1126/science.1254163

55. Lomovskaya O, Bostian KA. Practical applications and feasibility of efflux pump inhibitors in the clinic - a vision for applied use. Biochem Pharmacol. (2006) 71:910-8. doi: 10.1016/j.bcp.2005.12.008

56. Bowser TE, Bartlett VJ, Grier MC, Verma AK, Warchol T, Levy $\mathrm{SB}$, et al. Novel anti-infection agents: Small-molecule inhibitors of bacterial transcription factors. Bioorg Med Chem Lett. (2007) 17:5652-5. doi: 10.1016/j.bmcl.2007.07.072

57. Jeon B, Zhang QJ. Sensitization of Campylobacter jejuni to fluoroquinolone and macrolide antibiotics by antisense inhibition of the CmeABC multidrug efflux transporter. J Antimicrob Chemother. (2009) 63:946-8. doi: $10.1093 / \mathrm{jac} / \mathrm{dkp} 067$

58. Piddock LJV, Garvey MI, Rahman MM, Gibbons S. Natural and synthetic compounds such as trimethoprim behave as inhibitors of efflux in Gram-negative bacteria. J Antimicrob Chemother. (2010) 65:1215-23. doi: 10.1093/jac/dkq079

59. Piddock LJV. The crisis of no new antibiotics-what is the way forward? Lancet Infect Dis. (2012) 12:249-53. doi: 10.1016/S1473-3099(11)70316-4

60. Barczak AK, Hung DT. Productive steps toward an antimicrobial targeting virulence. Curr Opin Microbiol. (2009) 12:490-6. doi: 10.1016/j.mib.2009.06.012

61. Baron C. Antivirulence drugs to target bacterial secretion systems. Curr Opin Microbiol. (2010) 13:100-5. doi: 10.1016/j.mib.2009.12.003

62. Williams P. Quorum sensing, communication and cross-kingdom signalling in the bacterial world. Microbiology. (2007) 153:3923-38. doi: 10.1099/mic.0.2007/012856-0

63. Chen GZ, Swem LR, Swem DL, Stauff DL, O'Loughlin CT, Jeffrey PD, et al. A strategy for antagonizing quorum sensing. Mol Cell. (2011) 42:199-209. doi: 10.1016/j.molcel.2011.04.003

64. Garrity-Ryan LK, Kim OK, Balada-Llasat JM, Bartlett VJ, Verma AK, Fisher ML, et al. Small molecule inhibitors of lcrf, a yersinia pseudotuberculosis transcription factor, attenuate virulence and limit infection in a murine pneumonia model. Infect Immun. (2010) 78:4683-90. doi: 10.1128/IAI.01305-09

65. Ling LL, Schneider T, Peoples AJ, Spoering AL, Engels I, Conlon BP, et al. A new antibiotic kills pathogens without detectable resistance. Nature. (2015) 517:455-9. doi: 10.1038/nature14098

66. Blaskovich MAT, Zuegg J, Elliott AG, Cooper MA. Helping chemists discover new antibiotics. Acs Infect Dis. (2015) 1:285-7. doi: 10.1021/acsinfecdis.5b00044

67. Smith PA, Koehler MFT, Girgis HS, Yan D, Chen Y, Chen Y, et al. Optimized arylomycins are a new class of Gram-negative antibiotics. Nature. (2018) 561:189-94. doi: 10.1038/s41586-018-0483-6

68. Seal BS, Lillehoj HS, Donovan DM, Gay CG. Alternatives to antibiotics: a symposium on the challenges and solutions for animal production. Animal Health Res Rev. (2013) 14:78-87. doi: 10.1017/S14662523130 00030

69. Joerger RD. Alternatives to antibiotics: Bacteriocins, antimicrobial peptides and bacteriophages. Poultry Sci. (2003) 82:640-7. doi: 10.1093/ps/82.4.640

70. Liu GM, Wei Y, Wang ZS, Wu D, Zhou AG, Liu GL. Effects of herbal extract supplementation on growth performance and insulin-like growth factor (IGF)-I system in finishing pigs. J Animal Feed Sci. (2008) 17:538-47. doi: $10.22358 /$ jafs/66681/2008

71. Parisien A, Allain B, Zhang J, Mandeville R, Lan C. Novel alternatives to antibiotics: bacteriophages, bacterial cell wall hydrolases, and antimicrobial peptides. J Appl Microbiol. (2008) 104:1-13. doi: 10.1111/j.1365-2672.2007.03498.x

72. Sang Y, Blecha F. Antimicrobial peptides and bacteriocins: alternatives to traditional antibiotics. Animal Health Res Rev. (2008) 9:227-35. doi: 10.1017/S1466252308001497

73. Baltzer SA, Brown MH. Antimicrobial peptides-promising alternatives to conventional antibiotics. J Mol Microbiol Biotechnol. (2011) 20:228-35. doi: 10.1159/000331009

74. Savoia D. Plant-derived antimicrobial compounds: alternatives to antibiotics. Future Microbiol. (2012) 7:979-90. doi: 10.2217/fmb.12.68
75. Stanton TB. A call for antibiotic alternatives research. Trends Microbiol. (2013) 21:111-3. doi: 10.1016/j.tim.2012.11.002

76. Owens B. 2015 Nobel Prize goes to antiparasitic drug discoverers. Lancet. (2015) 386:1433. doi: 10.1016/S0140-6736(15)00455-9

77. Tu YY. The discovery of artemisinin (qinghaosu) and gifts from Chinese medicine. Nat Med. (2011) 17:1217-20. doi: 10.1038/nm.2471

78. Liu Y, Song M, Che TM, Bravo D, Pettigrew JE. Anti-inflammatory effects of several plant extracts on porcine alveolar macrophages in vitro. J Anim Sci. (2012) 90:2774-83. doi: 10.2527/jas.2011-4304

79. Liu Y, Che TM, Song M, Lee JJ, Almeida JA, Bravo D, et al. Dietary plant extracts improve immune responses and growth efficiency of pigs experimentally infected with porcine reproductive and respiratory syndrome virus. J Anim Sci. (2013) 91:5668-79. doi: 10.2527/jas.2013-6495

80. Liu Y, Song M, Che TM, Almeida JA, Lee JJ, Bravo D, et al. Dietary plant extracts alleviate diarrhea and alter immune responses of weaned pigs experimentally infected with a pathogenic Escherichia coli. J Anim Sci. (2014) 91:5294-306. doi: 10.2527/jas.2012-6194

81. Bontempo V, Jiang XR, Cheli F, Verso LL, Mantovani G, Vitari F, et al. Administration of a novel plant extract product via drinking water to postweaning piglets: effects on performance and gut health. Animal. (2014) 8:721-30. doi: 10.1017/S175173111400041X

82. Lan RX, Park JW, Lee DW, Kim IH. Effects of astragalus membranaceus, codonopsis pilosula and allicin mixture on growth performance, nutrient digestibility, faecal microbial shedding, immune response and meat quality in finishing pigs. J. Animal Physi Animal Nutr. (2017) 101:1122-9. doi: 10.1111 /jpn. 12625

83. Friedman, M. Chemistry, antimicrobial mechanisms, and antibiotic activities of cinnamaldehyde against pathogenic bacteria in animal feeds and human foods. J. Agric. Food Chem. (2017) 65:10406-23. doi: 10.1021/acs.jafc.7b04344

84. Gräber T, Kluge H, Granica S, Horn G, Kalbitz J, Brandsch C, et al. Agrimonia procera exerts antimicrobial effects, modulates the expression of defensins and cytokines in colonocytes and increases the immune response in lipopolysaccharide-challenged piglets. BMC Vet Res. (2018) 14:346. doi: 10.1186/s12917-018-1680-0

85. Du Z, Risu N, Gentu G, Cai Y. Growth performance, apparent digestibility, and $\mathrm{N}$ balance in Mongolian lambs and hoggs fed diets supplemented with a Chinese traditional herbal medicine complex. Anim Sci J. (2018) 89:1451-8. doi: 10.1111/asj.13081

86. Arnault I, Christides J, Mandon N, Haffner T, Kahane R, Auger J. Highperformance ion-pair chromatography method for simultaneous analysis of alliin, deoxyalliin, allicin and dipeptide precursors in garlic products using multiple mass spectrometry and UV detection. J Chromatogr. (2003) 991:69-75. doi: 10.1016/S0021-9673(03)00214-0

87. Koh KH, Tham FY. Screening of traditional Chinese medicinal plants for quorum-sensing inhibitors activity. J Microbiol Immunol. (2011) 44:144-8. doi: 10.1016/j.jmii.2009.10.001

88. Jakobsen TH, Bragason SK, Phipps RK, Christensen LD, van Gennip M, Alhede M, et al. Food as a source for QS inhibitors: iberin from horseradish revealed as a quorum sensing inhibitor of Pseudomonas aeruginosa. Appl Environ Microbiol. (2012) 78:2410-21. doi: 10.1128/AEM.05992-11

89. Jakobsen TH, van Gennip M, Phipps RK, Shanmugham MS, Christensen LD, Alhede M, et al. Ajoene, a sulfur-rich molecule from garlic, inhibits genes controlled by quorum sensing. Antimicrob Agents Chemother. (2012) 56:2314-25. doi: 10.1128/AAC.05919-11

90. Christensen LD, van Gennip M, Jakobsen TH, Alhede M, Hougen HP, Høiby $\mathrm{N}$, et al. Synergistic antibacterial efficacy of early combination treatment with tobramycin and quorum-sensing inhibitors against Pseudomonas aeruginosa in an intraperitoneal foreign-body infection mouse model. J Antimicrob Chemother. (2012) 67:1198-206. doi: 10.1093/jac/dks002

91. Picerno P, Mencherini T, Sansone F, Del Gaudio P, Granata I, Porta A, et al. Screening of a polar extract of Paeonia rockii: composition and antioxidant and antifungal activities. J Ethnopharmacol. (2011) 138:705-12. doi: 10.1016/j.jep.2011.09.056

92. Lau KM, Fu LH, Cheng L, Wong CW, Wong YL, Lau CP, et al. Two antifungal components isolated from Fructus Psoraleae and Folium Eucalypti Globuli by bioassay-guided purification. Am J Chin Med. (2010) 38:1005-14. doi: 10.1142/S0192415X10008421 
93. Falconieri D, Piras A, Porcedda S, Marongiu B, Gonçalves MJ, CAMRal $\mathrm{C}$, et al. Chemical composition and biological activity of the volatile extracts of Achillea millefolium. Nat Prod Commun. (2011) 6:1527-30. doi: 10.1177/1934578X1100601030

94. Laine TM, Lyytikäinen T, Yliaho M, Anttila M. Risk factors for post-weaning diarrhoea on piglet producing farms in Finland. Acta Vet Scand. (2008) 50:1-11. doi: 10.1186/1751-0147-50-21

95. Khan R, Islam B, Akram M, Shakil S, Ahmad AA, Ali SM, et al. Antimicrobial activity of five herbal extracts against multi drug resistant (MDR) strains of bacteria and fungus of clinical origin. Molecules. (2009) 14:586-97. doi: 10.3390/molecules 14020586

96. Dong S, Cai H, Liu Z, Zhang S, Chen C, Liu G, et al. Antidiarrheal effects and mechanisms of several Chinese medicinal herb extractions. J China Agric Univ. (2005) 10:60-4. doi: 10.3736/jintegrmed2013019

97. Borovan L. Plant alkaloids enhance performance of animals and improve the utilizability of amino acids. Krmivarstvi. (2004) 6:36-7.

98. Bomba A, Jonecová Z, Koščová J, Nemcová R, Gancarčíková S, Mudronová $\mathrm{D}$, et al. The improvement of probiotics efficacy by synergistically acting components of natural origin: a review. Biologia. (2006) 61:729-34. doi: 10.2478/s11756-006-0149-y

99. Li H, Wang H, Song J, Li X, Xie C. Climatic features and geographical distribution of medicinal plants in Xinjiang. Arid land Geograp. (2015) 38:36-42.

100. Aynazar Z, Ghopur M, Abdukadir A, Alimjan A, Gulzira Z. Isolation of endophytic bacteria from Algagi pseudalhagi Desv and analysis of active metabolites. J Northwest Botanical Sci. (2012) 32:1466-73. doi: 10.3969/j.issn.1000-4025.2012.07.028

101. Nathan C, Cars O. Antibiotic resistance - problems, progress, and prospects. N Engl J Med. (2014) 371:1761-3. doi: 10.1056/NEJMp14 08040

102. NHFPC. (2016). China National Action Plan to Contain Antimicrobial Resistance (2016-2020). National Health and Family Planning Commission of the P. R. China.

103. Yang H. China must continue the momentum of green law. Nature. (2014) 509:535-535. doi: 10.1038/509535a

104. Yang H, Huang X, Thompson JR, Flower RJ. Enforcement key to China's environment. Science. (2015) 347:834-5. doi: $10.1126 /$ science.347.6224.834-d

Conflict of Interest Statement: The authors declare that the research was conducted in the absence of any commercial or financial relationships that could be construed as a potential conflict of interest.

Copyright (c) 2019 Yang, Paruch, Chen, van Eerde, Skomedal, Wang, Liu and Liu Clarke. This is an open-access article distributed under the terms of the Creative Commons Attribution License (CC BY). The use, distribution or reproduction in other forums is permitted, provided the original author(s) and the copyright owner(s) are credited and that the original publication in this journal is cited, in accordance with accepted academic practice. No use, distribution or reproduction is permitted which does not comply with these terms. 